\title{
EFEK UMUR PEMANGKASAN INDIGOFERA (Indigofera zollingeriana) PADA MUSIM KEMARAU TERHADAP KANDUNGAN NETRAL DETERGEN FIBER DAN ACID DETERGEN FIBER
}

\author{
Effect of Harvest Age of Indigofera zollingeriana in Dry Season on Neutral Detergent Fiber \\ and Acid Detergent Fiber
}

\author{
Syahrio Tantalo, Liman, Farida Fathul
}

Department of Animal Husbandry, Faculty of Agriculture, University of Lampung

Jl. Soemantri Brojonegoro No. 1, Gedong Meneng, Rajabasa, Bandar Lampung 35145

E-mail: syahrio1961@gmail.com

\begin{abstract}
This research aims to determine the effect of harvest age Indigofera zollingeriana in dry season on the content of Neutral Detergent Fiber (NDF) and Acid Detergent Fiber (ADF). This research used a completely randomized design with four treatments and three replications. The treatment consisted of harvest age at 40 days, harvest age at 55 days, harvest age at 70 days, and harvest age at 85 days. Data were analyzed using Variance Analysis and post-hoc test of Least Significance Different (LSD). The parameters consisted of NDF and ADF. The results of this research indicate that Indigofera zollingeriana which was harvested at 55 days has the highest NDF content $(81.61 \%)$ and has significantly different ( $P$ $<0.01)$ than the NDF content at harvest age of 40 days (70.93\%), harvest age 70 days (68.80\%), and at harvest age 85 days (67.23\%). In addition, Indigofera zollingeriana that was harvested at 55 days has ADF content $(56.68 \%)$ and at 70 days of harvest had ADF content $(54.24 \%)$ that was significantly different $(P$ $<0.01)$ compared to ADF content at harvest age of 40 days by $48.35 \%$ and the harvest age of 85 days bay $49,41 \%$. It was concluded that Indigofera zollingeriana at the harvest age of 55 days in the dry season was the best harvest age with its NDF content of $81.61 \%$ and the ADF content of $56.68 \%$. Therefore, it is recommended to plant Indigofera zollingeriana in the dry season, and it should be harvested at the harvest age of 55 days.
\end{abstract}

Keywords: Acid Detergent Fiber, Dry season, Harvest Age, Indigofera zollingeriana, Neutral Detergent Fiber

\section{PENDAHULUAN}

Bahan sumber protein dalam pakan ternak umumnya didapat dari produk hewani atau nabati impor yang relatif mahal, saat ini telah banyak dilakukan upaya untuk mengganti sumber protein hewani yaitu dengan penggunaan hijauan legum. Salah satu jenis legum yang dapat digunakan adalah Indigofera sp. Indigofera $s p$. merupakan hijauan dari kelompok kacangan (Family fabaceae) dengan genus Indigofera sp. dan memiliki 700 spesies, salah satunya Indigofera zollingeriana. Indigofera zollingeriana dapat digunakan sebagai hijauan pakan ternak dan suplemen kualitas tinggi untuk ternak karena kandungan nutrisinya yang tinggi. Tanaman ini memiliki kandungan protein kasar yang tinggi setara dengan alfafa (25 -23\%), kandungan mineral yang tinggi ideal bagi ternak perah, struktur serat yang baik dan nilai kecernaan yang tinggi bagi ternak ruminansia. Selanjutnya disebutkan bahwa sebagai sumber protein, tepung daun Indigofera mengandung pigmen yang cukup tinggi seperti xantofil dan carotenoid, selain itu tanaman ini dapat dimanfaatkan sebagai pakan ternak yang kaya akan nitrogen, fosfor, kalium dan kalsium (Abdullah et al., 2010). Simanihuruk dan Sirait (2009) melaporkan bahwa kandungan protein kasar dan serat kasar Indigofera zollingeriana berumur 7 bulan yaitu berturutturut $24,17 \%$ dan $17,83 \%$ bahan kering.

Leguminosa tropis Indigofera zollingeriana merupakan jenis hijauan perdu yang belum banyak diekspos sebagai sumber pakan ternak dan relatif baru dikembangkan di Indonesia. Hijauan ini memiliki kemampuan adaptasi yang sangat baik terhadap kondisi lingkungan yang beragam, seperti tanah masam 
dan tanah dengan salinitas tinggi, serta toleran terhadap iklim kering yang panjang (Herdiawan dan Krisnan, 2014).

Kualitas nutrisi Indigofera zollingeriana dipengaruhi oleh produktivitas hijauan seperti proporsi daun dan batang. Tarigan (2009) melaporkan bahwa rataan proporsi daun dan batang Indigofera sp. pada umur panen 30 hari yaitu $2,61(72,3 \%: 27,7 \%)$, umur panen 60 yaitu $1,71(63,1 \%: 36,9 \%)$, sementara untuk umur 90 hari sebesar 0,66 (39,76\%: 60,24\%). Protein di daun lebih banyak dibandingkan pada batang hijauan. Abdullah dan Suharlina (2010) menyatakan bahwa konsekuensi perubahan komposisi ini adalah penurunan kualitas yang ditunjukan oleh penurunan kandungan protein dari $22 \%$ menjadi $20 \%$.

Lamanya umur panen berpengaruh terhadap proporsi daun dan batang menjadi lebih kecil. Umur panen juga mempengaruhi produktivitas lainnya seperti produksi segar dan bahan kering. Hasil studi Abdullah dan Suharlina (2010) menunjukkan bahwa semakin tua umur pemangkasan dari 38 hari menjadi 88 hari semakin meningkat proporsi daun tua dari $58,4 \%$ menjadi $75,3 \%$ dan semakin menurun proporsi daun muda dari $41,6 \%$ menjadi $24,7 \%$, meskipun produksi total hijauan meningkat dari $2.673 \mathrm{~kg}$ $\mathrm{BK} / \mathrm{Ha} /$ panen menjadi $5.410 \mathrm{~kg} \mathrm{BK} / \mathrm{Ha} /$ panen.

Semakin tua umur tanaman maka kadar serat kasar akan semakin meningkat. Hal ini disebabkan oleh umur tanaman yang semakin tua mempunyai komponen dinding sel yang tinggi. Sehubungan dengan perkembangan kedewasaan (umur tanaman) hijauan, maka akan terjadi pula peningkatan konsentrasi seratnya (Savitri et al., 2012).

Umur hijauan juga mempengaruhi produktivitas lainnya seperti produksi segar dan bahan kering. Menurut Tarigan (2009) rataan produksi bahan kering Indigofera $s p$. dengan umur panen 30 hari yaitu 16,26 ton/ha/tahun, umur panen 60 hari 21,18 ton/ha/tahun, sementara umur panen 90 hari yaitu sebesar 28,33 ton/ha/tahun. Umur panen yang terlalu lama akan meningkatan kandungan serat kasar hijauan. Prosea (1992) menyatakan bahwa hijauan pakan sebaiknya dipanen pada umur 40-45 hari saat musim penghujan dan umur 50-60 hari pada musim kemarau. Pemanenan yang dilakukan lebih dari 60 hari akan menyebabkan penurunan kandungan nutrisi karena batang hijauan semakin keras dan serat kasarnya tinggi. Kandungan nutrisi yang rendah tersebut dikhawatirkan dapat mempengaruhi produktivitas ternak, karena pada umumnya ternak lebih cenderung mengkonsumsi daun daripada batang.
Berdasarkan hal tersebut diperlukan upaya untuk tetap mempertahankan produktivitas hijauan Indigofera zollingeriana dengan kualitas yang cukup baik, selain itu ada informasi dari beberapa peneliti mengenai adanya keterkaitan antara umur panen dengan produktivitas (produksi segar, produksi bahan kering serta proporsi daun dan batang) hijauan Indigofera zollingeriana, yaitu produksi bahan kering Indigofera zollingeriana pada umur panen 90 hari masih cukup tinggi. Rekomendasi beberapa peneliti bahwa Indigofera zollingeriana sebaiknya dipanen pada umur 50-60 hari pada musim kemarau dan pada umur 40-45 hari saat musim penghujan, selanjutnya dinyatakan bahwa pemanenan yang dilakukan lebih dari 60 hari akan menyebabkan penurunan kandungan nutrisi karena batang hijauan semakin keras dan serat kasarnya tinggi. Berdasarkan pertimbangan tersebut maka perlu dilakukan penelitian perbedaan umur panen Indigofera zollingeriana pada kisaran umur panen 40-85 hari, oleh sebab itu penelitian ini dilakukan untuk mengetahui pengaruh perbedaan umur panen $(40,55,70$, dan 85 hari) terhadap kandungan NDF dan ADF hijauan Indigofera zollingeriana.

\section{MATERI DAN METODE}

\section{Materi}

Penelitian ini dilaksanakan pada Mei 2017 sampai dengan Agustus 2017 pada saat musim kemarau di Desa Purwodadi, Kecamatan Adiluwih, Kabupaten Pringsewu, Provinsi Lampung. Analisis Van Soest untuk mengetahui kadar NDF dan ADF dilakukan di Balai Penelitian Ternak Ciawi, Bogor.

\section{Metode}

Rancangan yang digunakan dalam percobaan ini yaitu, Rancangan Acak Lengkap. Data dianalisis dengan Analisis Ragam, bila hasilnya nyata dilanjutkan dengan uji Beda Nyata Terkecil pada taraf nyata 5\% dan 1\% (Steel and Torrie, 1993). Penelitian ini menggunakan empat perlakuan dengan tiga ulangan dengan jarak antar perlakuan \pm 1 meter. Perlakuan terdiri dari:

P40 : Indigofera dipanen umur 40 hari

P55 : Indigofera dipanen umur 55 hari

P70 : Indigofera dipanen umur 70 hari

P85 : Indigofera dipanen umur 85 hari

Prosedur penelitian ini terdiri dari beberapa tahap yaitu :

1. Pemetakan lahan dan pemangkasan awal Memetakan lahan menggunakan tali rafia dengan luas sebesar $2 \times 2 \mathrm{~m}^{2}$; pemangkasan 
awal dilakukan pada tanaman berumur $\pm 1,5$ tahun secara seragam, dan disisakan setinggi $\pm 80-90 \mathrm{~cm}$ di atas permukaan tanah.

2. Pemanenan hijauan Indigofera zollingeriana Panen hijauan Indigofera zollingeriana dilakukan dengan meninggalkan sisa tanaman setinggi $\pm 80-90 \mathrm{~cm}$ di atas permukaan tanah. Panen dilakukan pada hari ke-40, 55, 70, dan 85 setelah pemangkasan awal. Hasil panen ditimbang dan dicatat beratnya.

3. Persiapan sampel

Menimbang bahan masing-masing \pm 50 -700gr, kemudian dipotong sepanjang $\pm 1 \mathrm{~cm}$, timbang kembali bobotnya (A). Menuang potongan ke dalam nampan, menjemur di bawah sinar matahari selama \pm 3 hari (tergantung adanya sinar matahari) atau dikeringkan di dalam oven dengan suhu $60^{\circ} \mathrm{C}$ selama \pm 4 hari. Bahan tersebut sudah cukup dikeringkan apabila terasa kasat atau kering dan jika diremas mudah patah atau hancur; menimbang bahan (B), mengggiling bahan sampai halus; memasukan ke dalam kantong plastik dan memberi label, lalu mengaduknya agar homogen dan menghitung banyaknya air yang terkandung dalam bahan segar sampai menjadi tepung dengan cara berikut :

Kandungan air $($ gram $)=A-B$

Keterangan :

$\mathrm{A}=$ bobot bahan segar (gram)

$\mathrm{B}=$ bobot bahan kering udara (gram).

4. Analisis laboratorium

Untuk mengetahui kandungan NDF dan ADF, maka dilakukan analisis Van Soest dengan prosedur dari analisis Van Soest (1982).

\section{Peubah yang diamati}

Peubah yang diamati dan diukur pada penelitian ini yaitu kandungan neutral detergen fiber (NDF) dan acid detergen fiber (ADF).

\section{HASIL DAN PEMBAHASAN}

\section{Kandungan Neutral Detergen Fiber}

Neutral Detergen Fiber (NDF) merupakan zat makanan yang tidak larut dalam detergen netral, dan NDF merupakan bagian terbesar dari dinding sel tanaman. Bahan ini terdiri dari selulosa, hemiselulosa, lignin dan silika serta protein fibrosa (Van Soest, 1982). Berdasarkan analisis ragam menunjukkan bahwa perlakuan berpengaruh sangat nyata terhadap kandungan $\mathrm{NDF}$ Indigofera zollingeriana $(\mathrm{P}<0.01)$. Berdasarkan hasil uji BNT menunjukkan bahwa terdapat perbedaan yang sangat nyata $(\mathrm{P}<0.01)$ dari masing-masing perlakuan terhadap kandungan NDF Indigofera zollingeriana disajikan pada Tabel 1.

Tabel 1 menunjukkan Indigofera zollingeriana yang dipanen pada umur 55 hari (P55) memiliki kandungan NDF $(81,61 \%)$ yang tertinggi dan sangat nyata berbeda $(\mathrm{P}<0.01)$ dari pada perlakuan P40 (70,93\%). Penelitian ini dilakukan pada musim kemarau, membuktikan bahwa Indigofera zollingeriana yang dipanen pada umur 55 hari adalah waktu panen yang terbaik pada saat Indigofera zollingeriana ditanam pada musim kemarau. Fenomena ini sesuai dengan pendapat Prosea (1992) yang menyatakan bahwa hijauan sebaiknya dipanen pada umur 40-45 hari saat musim penghujan dan umur 50-60 hari pada musim kemarau.

Tabel 1. Kandungan Netral Detergen Fiber Indigofera zollingeriana pada umur panen yang berbeda

\begin{tabular}{ccccc}
\hline \multirow{2}{*}{ Ulangan } & \multicolumn{4}{c}{ Perlakuan (\%) } \\
\cline { 2 - 5 } & $\mathbf{P 4 0}$ & P55 & P70 & P85 \\
\hline 1 & 63,65 & 77,29 & 67,58 & 66,05 \\
2 & 71,23 & 83,85 & 76,91 & 72,67 \\
3 & 77,91 & 83,68 & 61,91 & 62,95 \\
\hline Rata-rata & $70,93 \pm 7,57^{\mathrm{ab}}$ & $81,61 \pm 3,74^{\mathrm{c}}$ & $68,80 \pm 7,13^{\mathrm{ab}}$ & $67,23 \pm 4,96^{\mathrm{a}}$ \\
\hline \hline
\end{tabular}

Keterangan : P40 = Indigofera panen pada umur 40 hari; P55 = Indigofera panen pada umur 55 hari; P70 = Indigofera panen pada umur 70 hari; P85 = Indigofera panen pada umur 85 hari. Huruf yang berbeda ke arah kolom menunjukkan perbedaan yang sangat nyata $(\mathrm{P}<0.01)$ pada uji BNT

Umur panen Indigofera zollingeriana pada 55 hari merupakan kisaran umur tanam Indigofera zollingeriana mulai berbunga. Hal ini sesuai dengan pendapat Abdullah (2014) yang menyatakan bahwa Indigofera sp. mulai berbunga sejak umur sekitar dua bulan (60 hari) setelah transplantasi yang masa transplantasi tersebut memerlukan waktu satu sampai dua bulan atau 30-60 hari, selain itu umur panen Indigofera zollingeriana pada 55 hari merupakan fase 
vegetatif sehingga terjadi peningkatan biomassa daun dan ranting yang dapat berpengaruh terhadap kandungan NDF-nya yang cenderung semakin tinggi. Abdullah (2014) menjelaskan bahwa hijauan akan terus mengalami pembelahan sel, pemanjangan sel, dan diferensiasi sel pada saat fase vegetatif sehingga terjadi peningkatan biomassa daun dan ranting, selain itu Polakitan dan Kairupan (2009) juga menjelaskan bahwa umur pemotongan hijauan pakan ternak sebaiknya dilakukan pada periode akhir fase vegetatif atau menjelang berbunga (fase generatif) untuk menjamin pertumbuhan kembali yang optimal dan kandungan nutrisi yang tinggi.

Hasil penelitian menunjukkan bahwa Indigofera zollingeriana yang dipanen pada umur 55 hari (P55) memiliki kandungan NDF $(81,61 \%)$ yang sangat nyata lebih tinggi $(\mathrm{P}<0.01)$ dari pada perlakuan P70 yaitu umur panen 70 hari $(68,80 \%)$, dan perlakuan $\mathrm{P} 85$ yaitu umur panen 85 hari $(67,23 \%)$. Keadaan ini membuktikan bahwa semakin lama umur panen Indigofera zollingeriana maka terjadi penurunan kandungan NDF nya yang disebabkan oleh batang hijauan Indigofera zollingeriana tersebut semakin keras dan serat kasarnya tinggi. Hal ini selaras dengan pendapat Prosea (1992) yang menyatakan bahwa pemanenan yang dilakukan lebih dari 60 hari akan menyebabkan penurunan kandungan nutrisi karena batang hijauan semakin keras dan serat kasarnya tinggi.

Tarigan (2009) menyatakan bahwa peningkatan umur hijauan diikuti dengan peningkatan pada produksi dan proporsi ranting, serta penurunan proporsi daunnya. Penurunan pada proporsi daun dan ranting akan berhubungan dengan peningkatan kandungan dinding sel (Savitri et al., 2012). Pendapat ini memperkuat hasil penelitian karena dengan peningkatan kandungan dinding sel akan meningkatkan juga kandungan NDF hijauan Indigofera zollingeriana yang dipanen pada umur 70 hari dan 85 hari (Tabel 1).

\section{Kandungan Acid Detergen Fiber}

Acid Detergen Fiber (ADF) merupakan zat makanan yang tidak larut dalam detergen asam yang terdiri dari selulosa, lignin dan silika (Van Soest, 1982). Komponen ADF yang mudah dicerna adalah selulosa, sedangkan lignin sulit dicerna karena memiliki ikatan rangkap. Selulosa merupakan polisakarida yang terdiri dari rantai lurus unit glukosa yang mempunyai berat molekul tinggi. Selulosa lebih tahan terhadap reaksi kimia dibandingkan dengan glukan lainnya (Tillman $e t$ al., 1989).

Berdasarkan analisis ragam menunjukkan bahwa perlakuan berpengaruh sangat nyata terhadap kandungan ADF Indigofera zollingeriana $(\mathrm{P}<0.01)$. Tabel 2 menunjukkan bahwa Indigofera zollingeriana yang dipanen pada umur 55 hari (perlakuan P55) yang memiliki kandungan $\mathrm{ADF}(56,68 \%)$ dan umur panen 70 hari (P70) dengan kandungan ADF $(54,24 \%)$ sangat nyata lebih tinggi $(\mathrm{P}<0.01)$ dibandingkan dengan kandungan ADF pada perlakuan P40 (umur panen 40 hari) sebesar $48,35 \%$ dan perlakuan P85 (umur panen 85 hari) sebesar $49,41 \%$. Secara rinci kandungan ADF Indigofera zollingeriana pada umur panen yang berbeda disajikan pada Tabel 2.

Tabel 2 menunjukkan bahwa kandungan ADF Indigofera zollingeriana yang dipanen pada umur 85 hari $(49,41 \%)$ tidak berbeda sangat nyata $(\mathrm{P}<0.01)$ dari pada kandungan ADF yang dipanen umur 40 hari $(48,24 \%)$, selain itu kandungan ADF Indigofera zollingeriana yang dipanen pada umur 85 hari tersebut sangat nyata $\mathrm{P}<(0.01)$ lebih rendah dibandingkan dengan kandungan ADF pada umur panen 55 hari dan 70 hari. Fenomena ini tidak seperti fenomena yang terjadi pada tanaman hijaun lainnya yang akan menunjukkan kecenderungan adanya peningkatan kandungan ADF pada umur panen yang semakin tua. Hasil penelitian ini perlu kajian atau penelitian lebih lanjut untuk mendapatkan jawaban terhadap fenomena tersebut.

Tabel 2. Kandungan Acid Detergen Fiber Indigofera zollingeriana pada umur panen yang berbeda

\begin{tabular}{ccccc}
\hline \multirow{2}{*}{ Ulangan } & \multicolumn{4}{c}{ Perlakuan $(\boldsymbol{\%})$} \\
\cline { 2 - 5 } & $\mathbf{P 4 0}$ & $\mathbf{P 5 5}$ & $\mathbf{P 7 0}$ & P85 \\
\hline 1 & 42,80 & 55,80 & 54,75 & 47,25 \\
2 & 46,70 & 61,63 & 57,10 & 49,10 \\
3 & 55,55 & 52,62 & 50,87 & 51,87 \\
\hline Rata-rata & $48,35 \pm 6,53^{\mathrm{a}}$ & $56,68 \pm 4,57^{\mathrm{b}}$ & $54,24 \pm 3,15^{\mathrm{b}}$ & $49,41 \pm 2,33^{\mathrm{a}}$
\end{tabular}

Keterangan : $\quad$ P40 = Indigofera panen pada umur 40 hari; P55 = Indigofera panen pada umur 55 hari; P70 = Indigofera panen pada umur 70 hari; P85 = Indigofera panen pada umur 85 hari. Huruf yang berbeda ke arah kolom menunjukkan perbedaan yang sangat nyata $(\mathrm{P}<0.01)$ pada uji BNT 
Berdasarkan hasil penelitian (Tabel 1) bahwa kandungan NDF Indigofera zollingeriana pada umur panen 55 hari $(81,61 \%)$ merupakan umur panen yang menunjukkan hasil kandungan NDF yang tertinggi dibandingkan dengan umur panen 40, 70, dan 85 hari yang menunjukkan kandungan hemiselulosa dan protein fibrosa yang terdapat dalam NDF cukup tinggi. Hal ini dibuktikan dengan kandungan ADF Indigofera zollingeriana pada umur panen 55 hari sebesar $56,68 \%$ (Tabel 2). Fenomena ini selaras dengan pendapat Van Soest (1982) yang menyatakan bahwa NDF terdiri dari hemiselulosa, selulosa, lignin dan silika serta protein fibrosa; sedangkan ADF merupakan zat makanan yang tidak larut dalam detergen asam yang terdiri dari selulosa, lignin dan silica. Berdasarkan data ini dapat diartikan bahwa Indigofera zollingeriana pada umur panen 55 hari merupakan umur panen yang terbaik berdasarkan kandungan NDF dan ADFnya. Kandungan NDF mewakili kandungan dinding sel yang terdiri dari lignin, selulosa, hemiselulosa dan protein yang berikatan dengan dinding sel, sedangkan ADF mewakili selulosa dan lignin dinding sel tanaman. Analisis ADF dibutuhkan untuk evaluasi kualitas serat untuk pakan ternak ruminansia dan herbivora lain. Untuk ternak non ruminansia dengan kemampuan pemanfaatan serat yang kecil, hanya membutuhkan analisis NDF (Suparjo, 2010). Lebih lanjut dipertegas oleh Sudirman et al. (2015) bahwa ADF dan NDF merupakan fraksi dinding sel dengan nilai cerna rendah. Oleh karena itu, dalam strategi formulasi ransum ternak sapi maupun ternak herbivora lainnya, keberadaan fraksi ADF dan NDF sangat urgen dipertimbangkan

\section{SIMPULAN DAN SARAN}

\section{Simpulan}

Indigofera zolllingeriana yang dipanen saat musim kemarau pada umur pemangkasan 55 hari merupakan umur panen yang terbaik dengan kandungan NDF sebesar $81,61 \%$ dan ADF sebesar $56,68 \%$.

\section{Saran}

Indigofera zollingeriana disarankan ditanam pada musim kemarau dan dipanen pada umur 55 hari. Perlu penelitian lebih lanjut terutama untuk mempelajari fenomena tentang umur panen Indigofera zollingeriana pada umur 85 hari yang relatif sama dengan kandungan ADF pada umur panen 40 hari. Fenomena ini tidak seperti fenomena yang terjadi pada tanaman hijauan lainnya yang akan menunjukkan kecenderungan adanya peningkatan kandungan ADF pada umur panen yang semakin tua.

\section{DAFTAR PUSTAKA}

Abdullah, L. 2014. Prospektif agronomi dan ekofisiologi Indigofera zollingeriana sebagai tanaman penghasil hijauan pakan berkualitas tinggi. J. Pastura 3(2): 79-83.

Abdullah, L and Suharlina, 2010. Herbage yield and quality of two vegetative parts of Indigofera at different time of first regrowth defoliation. Med. Pet. 1(33): 4449.

Abdullah, L. N.R. Kumalasari, Nahrowi, Suharlina, 2010. Pengembangan Produk Hay, Tepung dan Pelet Daun Indigofera sp. sebagai Alternatif Sumber Protein Murah Pakan Kambing Perah. Laporan Penelitian. Fakultas Peternakan Institut Pertanian Bogor. Bogor.

Fathul, F., 2017. Buku Penuntun Praktikum Penentuan Kualitas dan Kuantitas Kandungan Zat Makanan Pakan. Jurusan Peternakan. Fakultas Pertanian. Universitas Lampung. Bandar Lampung.

Herdiawan, I. dan R. Krisnan. 2014. Produktifitas dan Pemanfaatan Tanaman Leguminosa Pohon Indigofera zollingeriana pada Lahan Kering. Wartazoa 24(2): 75-82.

Polakitan, D. dan A. Kairupan. 2009. Pertumbuhan dan Produktivitas Rumput Gajah Dwarf (Pennisetum purpureum $C v$. Mott) pada Umur Potong Berbeda. Balai Pengkajian Teknologi Pertanian. Sulawesi Utara.

Prosea. 1992. Plant Resources of South-East Asian. No 4 Forages. L'tMannetje and R.M. Jones (Eds.). Prosea Foundation. Bogor.

Savitri, M. V., H. Sudarwati dan Hermanto. 2012. Pengaruh umur pemotongan terhadap produktivitas gamal (Gliricidia sepium). Fakultas Peternakan, Universitas Brawijaya. Malang.

Simanihuruk, K., dan J. Sirait. 2009. Pemanfaatan Leguminosa Pohon Indigofera sp. sebagai Pakan Basal Kambing Boerka Fase Pertumbuhan. Seminar Nasional Teknologi Peternakan dan Veteriner. Loka Penelitian Kambing Potong. Sumatera Utara.

Steel, R. G. D., and J. H. Torrie. 1993. Prinsip dan Prosedur Statistika: Suatu Pendekatan Biometrik. Terjemahan dari: Principles and Procedures of Statistics. Gramedia Pustaka Utama. Jakarta. 
Sudirman, Suhubdy, S. D. Hasan, S. H. Dilaga, dan I. W. Karda. 2015. Kandungan Neutral Detergent Fibre (NDF) dan Acid Detergent Fibre (ADF) bahan pakan lokal ternak sapi yang dipelihara pada kandang kelompok. Jurnal Ilmu dan Teknologi Peternakan Indonesia. 1(1):66-70.

Suparjo. 2010. Analisis Bahan Pakan Secara Kimiawi: Analisis Proksimat dan Analisis Serat. Labolatorium Makanan Ternak. Fakultas Peternakan. Universitas Jambi. Jambi.

Tarigan, A. 2009. Produktivitas dan Pemanfaatan Indigofera sp sebagai Pakan Ternak Kambing pada Interval dan Intensitas Pemotongan yang berbeda. Sekolah
Pascasarjana. Institut Pertanian Bogor. Bogor.

Tarigan, A., L. Abdullah, S. P. Ginting, dan I. G. Permana. 2010. Produksi dan Komposisi Nutrisi serta Kecernaan in Vitro Indigofera $s p$ pada Interval dan Tinggi Pemotongan Berbeda. JITV. 15:188-195.

Tillman, A. D, H. Hartadi, dan S. Reksohadiprodjo. 1989. Ilmu Makanan Ternak Dasar. Gadjah Mada University press. Yogyakarta.

Van Soest. P. J., 1982. Nutritional Ecology of the Ruminant. Commstock Publishing Associates. A devision of Cornell University Press. Ithaca and London. 